guideline committees, the problem now facing those who wish to get rid of public guidelines was neatly summed up by Mark Richmond, a member of the UK Genetic Manipulation Advisory Group. Publication of the Berg letter, he pointed out, was in effect a political act even though there had been no political intention. But through this political act the subject has lost its innocence, and it is now going to be hard for the scientists involved to regain a position in which their views can be regarded as objective.

"How are you going to reassure the public that you're not arguing from self-interest", said Richmond, "but that you are now arguing objectivelyparticularly when. looked at from the outside, you seem to make enormous quantum jumps between what you require for conditions at one time and what you required for the same experiments a couple of years ago".

R. Pritchard. Professor of Biochemistry at Leicester and a wellknown opponent of the UK GMAG reiterated his opinion that the effect of the Berg letter was largely due to the eminent names appended to it. and that its message could only be countermanded by the authors themselves. They should state publicly and unequivocally what they now believe. he said. to the loudest round of applause of the meeting.

Not all the participants, however. judged the display of public recantation before the Inquisition to be warranted. In the perception of a historian of science. Charles Weiner of MIT, the recombinant DNA debate has not been the wasteful and illborn episode it seems to most of those concerned.

Weiner has followed the tortuous course of the debate from the beginning and has collected in his Recombinant

\section{'Worst case' experiments show low risk}

THt: original fears which led to the call for a moratorium were largely prompted by the prospect that cloning animal viruses, and especially tumour viruses, would provide them with a new or more effective way of overcoming host defences. The first results, reported recently, from the $\mathrm{NIH}$ 'polyoma experiment' designed to test this proposition were reassuring. Tests of the infectivity of complete copies of polyoma DNA cloned in plasmids or phage lambda showed it to be non-infectious or much less infectious (by a factor of $\left.10^{4}\right)$ than polyoma virus itself.

One of the NIH experimenters, Dr M. Martin of the National Institute of Allergy and Infectious Diseases, told the Wye conference of results they now have on the tumorigenicity of cloned polyoma IDNA. E. coli carrying plasmids containing one copy of polyoma DNA produced no tumours when introduced into newborn hamsters; polyoma virus introduced in comparable conditions produces tumours in all animals infected.

DNA Archive at MIT much of the formal documentation, supplemented by the informal accounts of those involved. Although molecular biologists found the experience of coming face to face with the apprehensions of society a traumatic one, they have, in Weiner's opinion, come through with their science and honour relately unscathed.

Despite the trauma and despite the
The circular recombinant plasmid DNA itself produced a few tumours when given in quantities equivalent to $10^{6}$ times those at which polyoma virus is invariably tumorigenic. As expected from the previous infectivity experiments, bacteriophage lambdacontaining dimeric polyoma DNA also caused tumours in a few cases.

The NIH experiment was delayed first by the regulations against the cloning of animal viruses and then by a private legal suit brought against NIH which sought to prevent the experiment. A group of European scientists sponsored by EMBO to undertake similar polyoma infectivity experiments completed initial in vitro infectivity tests (which came to essentially the same conclusions as the NIH study) last year under the then less restrictive UK regulations, but have been unable to carry out animal infectivity or tumorigenicity tests because of the lack of any approved facility for such animal experiments in Europe.

In contrast to the US team they werc able to obtain dimeric polyoma DNA cloned in plasmids the NIH scientists could only obtain dimeric polyoma inserts in lambda) which will now be tested for animal infectivity and tumorigenicity at Fort Detrick.

bureaucracy said Weiner, recombinant DNA research flourishes. Has the whoie debate and its attendant publicity, he wondered, stimulated rather than repressed the research? But he was concerned at the attitude he now sees amongst younger scientists. to whom the message of the recombinant DNA debate now seems to be "shut up or be shut down".

\title{
US regulators countenance abolishment of the guidelines
}

InICATtoNs that the administrators most closely concerned are sympathetic to the efforts of the US scientific community to disentangle itself from the coils of recombinant DNA guidelines were provided by the statement at the conference from the Director of NIH, Donald Fredrickson.

Fredrickson's decision to go public on the proposed guidelines early in 1976 exposed the scientists to the full force of a public debate. But Fredrickson maintains that this was the only way to release the rising tension and "to prepare to defend whatever actions would be taken. against certain criticism".

The first NIH guidelines were released in June 1976. and greatiy relaxed guidelines came into force early this year. In his Wye address, Fredrickson described the latest guidc- lines as a "new set of rules painfully formulated during this unprecedented curtailment of experimentation in biology".

In his view one of the important achievements of the revision was to provide for continuous and orderiy evolution of the rules-"even to their eventual elimination when the need passes". Further revisions are due to come into force within the next few weeks. notably the approval of strains of Bacillus substilis and Succharomyces cerevisiae host-vector systems for various levels of containment, a provision hitherto lacking in the NIH guidelines.

H. DeWitt Stetten, former Chairman of the Director's Recombinant DNA Advisory Committee, used his talk to describe his personal route to disenchantment. After battling with the myriad inconsistencies embodied in the first guidelines he eventually came to the conclusion that they had "got off the track badly" and were doing things that were very wrong-given that the mission of NIH was to support and encourage research.

He decided that the hazards had becn overstated as no one could give him any evidence that there was any hazard. He concluded that "we had erected a bastion against a phantom". and that the barriers built to exclude ghosts were composed of scientists' time. effort and money. He has proposed that the guidelines be reduced to one simple rulc: "the appropriate conditions of containment for recombinant DNA experiments should be those of the most virulent microorganism entering into the experiment". 